\title{
The last Cretaceous ammonites in Latin America
}

Wolfgang Stinnesbeck, Christina Ifrim, and Christian Salazar

Acta Palaeontologica Polonica 57 (4), 2012: 717-728 doi: http://dx.doi.org/10.4202/app.2011.0042

Sections yielding late Maastrichtian ammonite assemblages are rare in Latin America and precise biostratigraphic correlation with European type sections remains difficult. In all, the extinction pattern of ammonites appears to differ between sites in southern high latitudes and those in the tropics to subtropics. In austral sections of Chile, and possibly also in southern Argentina, diverse assemblages range throughout most of the substage and then show a gradual decline prior to the Cretaceous-Paleogene (K-Pg) boundary. Further north, in northeast Brazil, only two genera (Diplomoceras, Pachydiscus) range into the uppermost Maastrichtian, but disappear within the last $0.3 \mathrm{Ma}$ of the Cretaceous. In tropical sections of Columbia and Mexico, the decline of ammonites started earlier and Sphenodiscus is the last ammonite known to occur in the late Maastrichtian. In all sections revised here the disappearance of ammonites was completed prior to the end of the Maastrichtian and was thus independent of the asteroid impact at, or near, the end of the Cretaceous.

Key words: Ammonoidea, Cretaceous-Paleogene (K-Pg) boundary, Maastrichtian, Chile, Argentina, South America, Mexico.

Wolfgang Stinnesbeck [wolfgang.stinnesbeck@geow.uni-heidelberg.de ], Christina Ifrim [christina.ifrim@geow.uni-heidelberg.de], and Christian Salazar [geosalazar@gmail.com], Institut für Geowissenschaften, Ruprecht-Karls-Universität, Im Neuenheimer Feld 234, D-69120 Heidelberg, Germany.

This is an open-access article distributed under the terms of the Creative Commons Attribution License (for details please see creativecommons.org), which permits unrestricted use, distribution, and reproduction in any medium, provided the original author and source are credited. 
FoF 